The University of Southern Mississippi

The Aquila Digital Community

Faculty Publications

$9-1-2005$

\title{
Writing Revolt In the Wake of Nat Turner: Frederick Douglass and the Construction of Black Domesticity In "The Heroic Slave"
}

Ellen M. Weinauer

University of Southern Mississippi, ellen.weinauer@usm.edu

Follow this and additional works at: https://aquila.usm.edu/fac_pubs

Part of the English Language and Literature Commons

\section{Recommended Citation}

Weinauer, E. M. (2005). Writing Revolt In the Wake of Nat Turner: Frederick Douglass and the Construction of Black Domesticity In "The Heroic Slave". Studies In American Fiction, 33(2), 193-202.

Available at: https://aquila.usm.edu/fac_pubs/2665

This Article is brought to you for free and open access by The Aquila Digital Community. It has been accepted for inclusion in Faculty Publications by an authorized administrator of The Aquila Digital Community. For more information, please contact Joshua.Cromwell@usm.edu. 


\title{
WRITING REVOLT IN THE WAKE OF NAT TURNER: FREDERICK DOUGLASS AND THE CONSTRUCTION OF BLACK DOMESTICITY IN "THE HEROIC SLAVE”
}

\author{
Ellen Weinauer \\ University of Southern Mississippi
}

One of the most striking aspects of the 1831 Confessions of Nat Turner is the text's sensationalized depiction of the annihilation of family. After describing the Turner band's initial "work of death"the "murder of [the Travis] family, five in number," including a "little infant sleeping in a cradle"- the text follows the slave rebels as they march from house to house, felling men, women, and children with axes, swords, guns, and clubs. ${ }^{1}$ The text documents the pleasure Turner takes in the group's often prolonged acts of murder ("I . . . viewed the mangled bodies as they lay, in silent satisfaction, and immediately started in quest of other victims") and the group's slaughter of even the most seemingly innocent whites: we "murdered Mrs. Reese in her bed, while sleeping," Turner explains; "her son awoke, but it was only to sleep the sleep of death, he had only time to say who is that, and he was no more."2 The question of authorship with regard to The Confessions - an ostensible "as told to" prison confession that is peppered with often unmarked interjections by interviewer/editor Thomas Gray himself-is an admittedly complex one: to what extent does the narrative remain under Gray's control, and where does Turner emerge from his interlocutor's frame to tell his own story? But regardless of whether one reads The Confessions as belonging primarily to Gray or to Turner, it is hard to miss its emphasis on Turner's savagery, linked insistently to Turner's desire to penetrate, and destroy, the spiritual heart of antebellum white civilization: the family.

As an exemplar of slave resistance, Turner posed difficulties for an antislavery movement that was in its earliest stages of organization and was, therefore, reluctant to endorse violence of any sort-least of all the seemingly indiscriminate, purposeless, and anti-family violence in which Turner and his men were alleged to have engaged. It is in an 1832 issue of the Liberator, for example, that we find Turner, a "sable fiend," gloating over the corpses of a "babe" whose "bruised lips" are "dashed with blood" and an "unripened virgin" who lies on "the cold hearth stone." 3 Ten years after Turner, however, abolitionists found a model of what one critic has called "righteous slave rebellion": Madison Washington, who in 1841 led a far less bloody, and arguably far 
more successful, revolt on board the slave ship Creole. ${ }^{4}$ On the Creole, en route from Virginia to the slave market in New Orleans, Washington, with the help of three other men, led a group of nineteen slaves in a revolt that would leave all of the ship's 135 slaves free in Nassau and that resulted in only two deaths, one white, one black. ${ }^{5}$ Importantly, even white witnesses to and participants in the events on board the Creole described Madison Washington as a man of restraint, humanity, and self-control - as the diametrical opposite of Nat Turner and, thus, an appealing figure around which to focus the public understanding of black resistance. It is no wonder, then, that Washington is invoked over and over again - most centrally, but certainly not exclusively, as the titular "Heroic Slave" of Frederick Douglass's 1853 novella - in the writings of antislavery activists as a righteous rebel, both resistant and compassionate, a fighter and a friend. ${ }^{6}$

But while abolitionists turned to Washington partly in an effort to undo Nat Turner's grip on historical consciousness, it was not so easy to shake that grip loose. Just as Turner can be seen to exert a shaping force on Gray's editorship of the Confessions, so too does he shape and influence the story that others would seek to tell of Madison Washington and the Creole affair. The horrors of Turner's ostensible anti-domestic agenda hover over retellings of the later revolt, directing the terms of those retellings and generating in them both intriguing "facts" and conspicuous gaps. Focusing on Douglass's "The Heroic Slave," this essay explores one such retelling and the ways in which Turner's story might be seen to shadow and shape it. In the context of Nat Turner's bloody rebellion, representing the Creole revolt becomes, in part, a question of how to represent the heretofore unrepresentable: noble slave resistance, black male heroism in the cause of freedom, and black regard for (black) domesticity and the (black) family. But while "The Heroic Slave" is able effectively to represent Madison Washington's heroism and the righteousness of his cause, it founders in telling the story of black domesticity - in part, I would argue, because that story requires the embodiment of that which proves to be a legally disembodied, even a gothic, figure: the slave-wife.

In January of 1842, just two months after the events on board the Creole took place, the Liberator published "The Creoles-Strike for Liberty!-The Hero Mutineers," an early treatment that, as its title suggests, lays the groundwork for future interpretations of the revolt as a story of legitimate rebellion against an unjust institution. The Liberator's account is interesting not only because of its effort to place Madison Washington in a genealogy of noble American revolutionar- 
ies-his "perfect preparation for the grand alternative of liberty or death" is, we are told, a "splendid exemplification[] of the true heroic"-but also because it stops to reflect on Washington's gentleness, his "generous leniency" as he "dressed the wounds of the poor [white] sailors who had fought against him." "The effort to displace the image of a savage Nat Turner with that of a nurturing Washington becomes even more central in a second report in the Liberator, where we witness what is, essentially, the invention of a love plot for the virtually unknown Washington. As William L. Andrews has noted, while Washington's "story seemed full of potential" for the cause of abolition, "so few facts were known about the man that no one knew how to turn ... him into a hero." ${ }^{8}$ Stepping into the breach, in June of 1842 the Liberator attempted to flesh out some of the facts of Washington's still-obscure life. In "Madison Washington: Another Chapter in His History," the Liberator makes use of loosely corroborated information from a Canadian abolitionist to weave a domestic, and romantic, back-story for Washington's resistance on board the Creole. According to this report, Washington had escaped successfully to Canada and had lived there for "some time ... - -long enough to love and rejoice in British liberty"; but although he loved freedom, he "loved his wife, who was left in Virginia, still more." He thus returns to the south to attempt to free his wife, whereupon, the Liberator "infer[s]," he "was himself re-enslaved" and placed on the Creole to be sold in the New Orleans slave market. The Liberator's report then steps further into the realm of speculation. The depositions that followed the Creole affair placed Washington in the cabin designated for slave women at the outbreak of violence. "Remember[ing]" that "it was Madison's visit 'aft among the women' that led to the first act of violence on the Creole," the Liberator offers a conjecture: "Might not [Washington's] wife have been there among the women? Yes, and this grave Creole matter may prove to have been but a part only of that grand game, in which the highest stake was the liberty of his dear wife."

The Liberator was not alone in its desire to "read" a "romantic dimension to Washington's story ... into the scanty facts it had amassed about his pre-Creole past." ${ }^{10}$ Indeed, its treatment followed that of another antislavery publication, the National Anti-Slavery Standard, which noted in April 1842 that "We would give much to learn whether [Washington's wife] was on board the Creole." Referring to the international struggle over legal jurisdiction that followed in the wake of the revolt, the Standard notes that "It would be curious indeed, if this little sub-plot of domestic love should set in motion a great game of nations." 11 This effort to locate such a "little" romantic "sub-plot" as 
the central motivation for Washington's "strike for liberty" seems trivial and depoliticizing at first blush; but if we recall both the persuasive force of antebellum domestic ideology and the long shadow cast by Turner's rebellion and his Confessions, just ten years prior, those romanticizing gestures become more substantive and significant. The absence of Nat Turner's wife from the Confessions has long been a matter of scholarly debate: although contemporary accounts took note of both Turner's wife and his children, not a single such family member is mentioned in the 1831 Confessions. ${ }^{12}$ It may be that Gray sought to omit Turner's wife from the narrative as a means of further stressing Turner's atavistic, anti-domestic barbarity. Alternatively, as scholars have recently suggested, Turner himself may have edited his wife and children out of his story in order to offer them a modicum of protection from brutalizing whites bent on revenge in the wake of the revolt. ${ }^{13}$ Regardless, the fact that Turner emerges from the Confessions as a man without (regard for) family, I would argue, influences later efforts to turn Madison Washington into, precisely, an exemplary family man. To make Madison Washington a "slave revolutionary whom whites could admire instead of fear"14 and to displace the connections left by Turner between slave insurrection and destruction of the (white) family, contemporary accounts like those in the Liberator are seemingly required to find him a wife. Yet, as Frederick Douglass's treatment of Madison Washington will suggest, the slavewife's story is one that resists representation, one that cannot, on some level, be told.

From early on in his writing and speaking career, Frederick Douglass followed the lead of the Liberator and other antislavery periodicals in citing Washington as a counterexample to Turner, a reminder to white readers of black capacities for affective bonds and the black commitment to domesticity. In an 1845 speech given in Ireland, for example, Douglass notes that "there are charges brought against coloured men not alone of intellectual inferiority, but of want of affection for each other. I do know that their affections are exceedingly strong. Why, but a short time ago we had a glorious illustration of affection in the heart of a black man-Maddison [sic] Washington ...."15 Douglass goes on to recount the story of Washington's return to Virginia from Canada to free his wife and "little ones," his seizure, and the "love of freedom" that fuelled his "determination to get [freedom] or die in the attempt." Although he presents Washington as a heroic figure who acts, in his effort to gain liberty, "in imitation of George Washington," he keeps the affective narrative in the forefront of his 
depiction. "We are branded as not loving our brother and race," he reiterates; but if this is so, then "Why did Maddison [sic] Washington leave Canada where he might be free, and run the risk of going to Virginia?"16

Not surprisingly, as Douglass begins to move away from William Lloyd Garrison and his abolitionist dicta, shifting toward a more militant antislavery stance, we can see some adjustments in his treatment of Madison Washington. In 1847, for example, Washington is not a family man but a "noble Negro" who "broke his fetters on the deck of the Creole" and "achieved liberty for himself and 135 others." More strikingly, in 1848 Douglass dares to link Washington and Nat Turner in a genealogy of resistance: there are, he insists, "many Madison Washingtons and Nathaniel Turners in the South, who would assert their right to liberty, if you would take your feet from their necks."17 If in this speech Douglass seems to have cast aside the need for a domesticated Washington who serves as a reassuring foil for Turner, in his 1849 "Slumbering Volcano" speech we witness once again complex maneuvering around Turner's legacy. As in 1848, in this speech Douglass reminds his audience that "the slaveholders are sleeping on slumbering volcanoes, if they did but know it," and that "there are some Madison Washingtons in this country." But although he recalls for his listeners the "sable arms" that are waiting to "spread death and devastation" throughout the slaveholding South, Douglass eschews any reference to Turner and restores Madison Washington to the affective narrative in which he had first presented him, emphasizing as he did in 1845 , and to an arguably greater extent, Washington's intense commitment to liberating his wife. ${ }^{18}$

It is, of course, in Douglass's 1853 novella, "The Heroic Slave," that we see his most extensive treatment of Madison Washingtonand, not surprisingly, his most extensive attention to the putative story of Washington's wife and family. As he constructs a speculative history out of the "marks, traces, possibles, and probabilities" left by the slave in the historical record, Douglass makes domestic affection a central component of his hero's character. ${ }^{19}$ At the beginning of the narrative, Washington (in a dramatic monologue overheard by a sympathetic white man, aptly named "Listwell") wavers between "declaration[s] of his purpose to be free" and declarations of love for his wife: "How can I leave her? Poor thing! What can she do when I am gone? Oh! Oh! 'tis impossible that I can leave poor Susan!" (29). ${ }^{20}$ As he later explains to Listwell, "The thought of leaving my poor wife and two little children caused me indescribable anguish" (35). Douglass seems unable to determine what to do with the children, who appear 
here and then drop out of the novella altogether. "Poor Susan," however, remains an oft-cited figure; by contrast with Turner's Confessions, which makes not a single mention of the slave-wife, Douglass's text repeatedly stresses Washington's attachment to, and at times dependence upon, his wife: she helps sustain him during a five-year sojourn as a fugitive in a nearby swamp, functions as his "good angel" (37), and is acknowledged for her "virtuous fidelity and undying affection" (56). Echoing Douglass's prior speeches, in "The Heroic Slave" Washington is haunted by the thought of his wife's enslavement and returns from liberty in Canada in order to free her. Fleshing out some of the intimations made by the Liberator back in 1842, Douglass describes how Susan is shot while the couple attempts to flee, how Washington "stood [his] ground and awaited [the] attack [of their pursuers] over her dead body," and how he was "knocked down," "overpowered," remanded back into slavery (57), and placed for sale on the Creole.

Here, then, Douglass once again accedes to the logic that Turner's Confessions set in motion-a logic that compels him to place a "little sub-plot of domestic love" at the heart of the story of Washington's revolt. But Douglass never seems fully able to realize that plot-for although he tries to make Susan Washington central to the Creole narrative, she remains faceless, non-descript. Her agency occluded (she is a "poor wife"), her voice muted (in a novella obsessed with speech, she says not a single word), Douglass's slave-wife is present but largely disembodied, a shadowy ghost of a character. For many critics, the elision of Susan Washington in "The Heroic Slave" signals Douglass's investment in an ideology of masculinity that required the assertion of male autonomy and the concomitant containment of female agency. ${ }^{21}$ But while Douglass's increasing commitment to such an ideology seems to be at work in "The Heroic Slave," we might also supplement and complicate our understanding of Susan Washington's textual occlusion by considering the representational difficulty posed by the figure of the "slave-wife" more generally.

Douglass devotes the first chapters of his 1855 autobiography, $M y$ Bondage and My Freedom, to the ways in which the laws of slavery deprive such identities as "mother," "father," "brother," and "sister" of meaning. His mother, he notes, has "many children, but NO FAMILY!", for the "domestic hearth" is "abolished" for her. Slavery has "robbed" the "terms" "brother and sister" of "their true meaning" and similarly "does away with fathers." Indeed, "Slavery has no use" at all for either "fathers or families, and its laws do not recognize their existence." 22 Nor, of course, did the laws of slavery recognize the exist- 
ence of the "slave-wife," whose familial obligations obstructed the smooth economic working of the traffic in human beings. But the slave-wife's condition is rendered even more complicated by the ways in which she exists at the intersection of two fundamentally incompatible proprietary systems: matrimony and slavery. Both systems sought to claim absolute ownership in their female subjects, leaving the slave-wife in a position of doubled subordination that is impossibly redundant. She cannot be a wife, because she is a slave and unable to enter into a marriage contract; but she cannot be a slave, because she is a wife, her identity "incorporated ... into that of her husband, under whose wing, protection, and cover she performs every thing." ${ }^{23}$ As these two proprietary systems collide over her, the slave-wife is categorically displaced, exiled from any normative subject position. ${ }^{24}$ She is thus suspended in a state of subjective indeterminacy that Kelly Hurley has argued is a central component of gothic texts: she "exist[s] across multiple categories of being and conform[s] cleanly to none of them." ${ }^{25}$ As the law over-structures her, the slave-wife becomes a kind of extra-legal, excessive entity; she becomes, in short, a gothic subject. It is perhaps no wonder, then, that in "The Heroic Slave" Madison Washington finds himself haunted by his wife: "She was in all my thoughts by day, and my dreams by night," he tells Listwell. ${ }^{26}$

I do not mean to suggest that Douglass used "The Heroic Slave" as a vehicle by which to comment on the erasure at law of the feme covert slave. Rather, I am suggesting, such disabilities shape, perhaps inevitably and often unwittingly, how Douglass's story of black domesticity gets told, introducing an unexpectedly gothic strain into a narrative meant in part to counter Nat Turner's tale of gothic horror. Indeed, Douglass and others who write about slave revolt in the wake of Turner face a kind of impossible task. Haunted by Turner's incursions against the family, the subsequent story of slave revolt requires an account of black domesticity that will bring resistance out of the realm of terror and into rational representation. Such an account, in turn, paradoxically requires that which cannot, on some level, be represented: the slave-wife. By recognizing the conundrum posed by the figure of the slave-wife, then, we might deepen our reading of the ghostly shades and shadows that filter through representations of black domesticity in a variety of texts, from Hannah Craft's The Bondwoman's Narrative (ca. 1850s) to Harriet Beecher Stowe's Uncle Tom's Cabin (1851-52) to William Craft's Running a Thousand Miles for Freedom (1861). In any event, we can certainly make more sense, and more substance, out of Susan Washington's shadowy presence in "The Heroic Slave." When read in light of the legal disabilities of the 
feme covert slave, indeed, Susan Washington can be seen to play a central role in Douglass's novella, marking through her ghostly status the representational erasures that slavery and marriage, working in tandem, effect. "Better... imagined than described," as William Wells Brown put it in his own version of the Creole affair, ${ }^{27}$ the wife who is meant to usher resistance out of the realm of the gothic is herself a gothic figure, part of slavery's own terrifying machinery.

\section{Notes}

${ }^{1}$ Thomas R. Gray, ed. The Confessions of Nat Turner (1831) in Nat Turner's Slave Rebellion, ed. Herbert Aptheker (New York: Humanities Press, 1966), 138, 139.

${ }^{2}$ Gray, 142, 140.

${ }^{3}$ Quoted in Eric J. Sundquist, To Wake the Nations: Race in the Making of American Literature (Cambridge, Mass, and London: Harvard Univ. Press, 1993), 53. Sundquist's book offers an extensive and provocative analysis both of the Confessions of Nat Turner (in particular, of the "parasitic rhetorical relationship" [48] between Turner and Thomas Gray, his interlocutor) and of the ways in which Turner and his text shape and motivate the writings of Frederick Douglass, particularly in My Bondage and My Freedom.

${ }^{4}$ Maggie Montesinos Sale, "To Make the Past Useful: Frederick Douglass' Politics of Solidarity," Arizona Quarterly 52 (1995), 53.

${ }^{5}$ A contemporary account of the Creole affair, albeit one that includes testimony of exclusively white witnesses, can be found in Senate Documents, $27^{\text {th }}$ Congress, $2^{\text {nd }}$ Sess., II. No 51 (1841-1842), 1-46. For a useful overview, see Howard Jones, "The Peculiar Institution and National Honor: The Case of the Creole Slave Revolt," Civil War History 21, no. 1 (1975), 28-50. In "To Make the Past Useful," Sale draws extensively on the Creole newspaper archive in order to illuminate what she sees as the radical political interventions of Douglass's "The Heroic Slave."

${ }^{6}$ Other contemporary accounts include those by William Wells Brown, who returned to Madison Washington repeatedly throughout the 1860s, and Lydia Maria Child. See William Wells Brown, "Madison Washington," in The Black Man: His Antecedents, His Genius, His Achievements (New York: Thomas Hamilton, 1863), 75-85; and Lydia Maria Child, "Madison Washington," in The Freedmen's Book (Boston: Ticknor and Fields, 1866). Pauline Hopkins treated Washington in "A Dash for Liberty," Colored American Magazine, August 1901, 243-47. For discussions of the revisions worked on the Madison Washington story, and their significance, see Celeste-Marie Bernier, "'Arms Like Polished Iron': The Black Slave Body in Narratives of Slave Ship Revolt," Slavery and Abolition 23 (2002), 91-106; and John C. Gruesser, "Taking Liberties: Pauline Hopkins's Recasting of the Creole Rebellion," in The Unruly Voice: Rediscovering Pauline Hopkins, ed. 
John Cullen Gruesser (Urbana and Chicago: Univ. of Illinois Press, 1996), 98-118.

7 "The Creoles - Strike for Liberty! - The Hero Mutineers," Liberator, January 7 , 1842.

${ }^{8}$ William L. Andrews, "The Novelization of Voice in Early African American Narrative," PMLA 105 (1990), 28. After the ship's arrival in Nassau, Washington seems to have walked off the Creole and into obscurity.

9 "Madison Washington: Another Chapter in His History," Liberator, June 10, 1842.

${ }^{10}$ Andrews, 28.

1 "Madison Washington," National Anti-Slavery Standard, April 28, 1842.

${ }^{12}$ See, for example, an article from the Richmond Constitutional Whig, in Henry Irving Tragle's extremely useful The Southampton Revolt of 1831: A Compilation of Source Material (Amherst: Univ. of Massachusetts Press, 1971), 90-99; Turner's wife is mentioned on 92 .

${ }^{13}$ For a summary of this argument and a discussion of the debate that emerged over William Styron's decision to omit Turner's wife from his controversial Confessions of Nat Turner, see Ashraf H. A. Rushdy, Neo-Slave Narratives: Studies in the Social Logic of a Literary Form (New York: Oxford Univ. Press, 1999), 60 and 77-78.

${ }^{14}$ Andrews, 28.

${ }^{15}$ Frederick Douglass, "American Prejudice Against Color" in The Frederick Douglass Papers, Vol. 1, ed. John W. Blassingame (New Haven and London: Yale Univ. Press, 1979), 68.

${ }^{16}$ Douglass, "American Prejudice," 67, 68, 68-69.

${ }^{17}$ Frederick Douglass, "Farewell Speech to the British People," in The Life and Writings of Frederick Douglass, Vol 1, ed. Philip Foner (New York: International Publishers, 1950), 228; Frederick Douglass, "The Slaves' Right to Revolt," in The Frederick Douglass Papers, Vol. 2, ed. John W. Blassingame (New Haven and London: Yale Univ. Press, 1982), 131.

${ }^{18}$ Frederick Douglass, "Slavery, the Slumbering Volcano," in The Frederick Douglass Papers, Vol. 2, 151, 153. In this speech, Douglass mentions Washington's wife six times in the space of one paragraph (154-55).

${ }^{19}$ Frederick Douglass, "The Heroic Slave," in Three Classic African-American Novels, ed. William L. Andrews (New York:, Mentor, 1990), 26. Hereafter cited parenthetically. 
${ }^{20}$ Interestingly, in addition to identifying Washington as a husband and father, "The Heroic Slave" repeatedly frames him in terms of other familial relationships and identities: he is a child of Virginia (25), for example, and as we seek for elusive information about him in the (white-authored) historical record we are "like a weary and disheartened mother" in "search for a lost child" (26).

${ }^{21}$ See, for example, Richard Yarborough, "Race, Violence, and Manhood: The Masculine Ideal in Frederick Douglass's 'The Heroic Slave,'” in Frederick Douglass: New Literary and Historical Essays, ed. Eric J. Sundquist (Cambridge: Cambridge Univ. Press, 1990), 166-88; Jenny Franchot, "The Punishment of Esther: Frederick Douglass and the Constitution of the Feminine," in Frederick Douglass: New Literary and Historical Essays, 141-65; P. Gabrielle Foreman, "Sentimental Abolition in Douglass's Decade: Revision, Erotic Conversion, and the Politics of Witnessing in 'The Heroic Slave' and My Bondage and My Freedom," in Criticism and the Color Line: Desegregating American Literary Studies, ed. Henry B. Wonham (New Brunswick: Rutgers Univ. Press, 1996), 191-204; and Maggie Montesinos Sale, "Critiques from Within: Antebellum Projects of Resistance," American Literature 64 (1992), 695-718.

${ }^{22}$ Frederick Douglass, My Bondage and My Freedom (1855; New York: Penguin, 2003), 39, 40, 41.

${ }^{23}$ William Blackstone, Commentaries on the Laws of England, Vol. 1, 1765 (Chicago: Univ. of Chicago Press, 1979), 430. Blackstone's book was a kind of handbook for American lawyers in the early Republican and antebellum periods.

${ }^{24}$ For a case that illustrates the slave-wife's fundamental non-meaning under the law, and a discussion of her destabilizing effects on the functioning of the legal system, see Ellen Weinauer, “'A Most Respectable Looking Gentleman’: Passing, Possession, and Transgression in Running a Thousand Miles for Freedom," in Passing and the Fictions of Identity, ed. Elaine K. Ginsberg (Durham: Duke Univ. Press, 1997), 42-43.

${ }^{25}$ Kelly Hurley, The Gothic Body: Sexuality, Materialism, and Degeneration at the Fin de Siècle (Cambridge and New York: Cambridge Univ. Press, 1996), 24.

${ }^{26}$ This is a direct echo of Douglass's description, in his "Slumbering Volcano" speech, of the ways in which Washington's wife "came back to his mind to trouble his peace and disturb his slumbers" (155).

${ }^{27}$ Brown, 84 . 